\title{
IDENTIFIKASI METABOLIT SEKUNDER, UJI TOKSISITAS,DAN UJI ANTIOKSIDAN EKSTRAK KULIT BATANG TERAP (Artocarpus odoratissimus blanco)
}

\author{
Fadhli Nurrahman W*, Vina Maulidya, Laode Rijai \\ Laboratorium Penelitian dan Pengembangan FARMAKA TROPIS, Fakultas \\ Farmasi Universitas Mulawarman, Samarinda, Kalimantan Timur \\ *Email: Fazlimubarak01@gmail.com
}

\begin{abstract}
ABSTRAK
Terap (Artocarpus odoratissimus) merupakan salah satu tumbuhan daerah tropis yang memiliki potensi sebagai sumber bahan kimia bioaktif. Penelitian ini bertujuan untuk mengetahui kandungan metabolit sekunder serta aktivitas antioksidan dan toksisitas dari kulit batang terap. Langkah penelitian ini meliputi proses maserasi menggunakan pelarut metanol, setelah itu dilakukan pemekatan ekstrak menggunakan Rotary evaporator. Metabolit sekunder yang terdapat dalam ekstrak kulit batang terap yaitu flavonoid, fenolik, tannin, saponin, dan triterpenoid. Aktivitas antioksidan secara spektrofotometri UV-VIS menggunakan metode DPPH (1,1-dyphenyl-2-picrylhidrazyl) memiliki nilai $\mathrm{IC}_{50} 50 \mathrm{ppm}$ dan aktivitas toksisitas menggunakan metode BSLT memiliki nilai LC L $_{50} 462,38$ ppm.
\end{abstract}

Kata kunci : DPPH (1,1-dyphenyl-2-picrylhidrazyl), BSLT, Antioksidan, Toksisitas, Metabolit Sekunder.

\begin{abstract}
Terap (Artocarpus odoratissimus) is a tropical plant that has potential as a source of chemical bioaktif. This research aims to know the content of secondary metabolites as well as antioxidant activity and toxicity of bark terap. These include the research process step maceration using methanol solvent, after it's done pemekatan extract using the Rotary evaporator. Secondary metabolites found in extracts of bark phenolic flavonoids, namely terap, tannins, saponins, and triterpenoid. Antioxidant activity in UV-VIS spectrophotometry using DPPH method (1.1-dyphenyl-2-picrylhidrazyl) has an IC50 value of $50 \mathrm{ppm}$ and the activity of the BSLT method using toxicity has a value of 462.38 ppm LC50.
\end{abstract}

Keywords: DPPH (1.1-dyphenyl-2-picrylhidrazyl), BSLT, antioxidants, toxicity, secondary metabolites 


\section{PENDAHULUAN}

Bangsa Indonesia sudah mengenal dan memakai tumbuhan berkhasiat obat sebagai salah satu upaya penanggulangan masalah kesehatan yang dihadapi yang dikenal dengan pengobatan secara tradisional. Pengobatan secara tradisional sebagian besar ramuan berasal dari tumbuh-tumbuhan baik berupa akar, kulit, batang, kayu, daun, bunga atau biji. Pengobatan secara tradisional dapat dipertanggungjawabkan dengan melakukan penelitian ilmiah seperti penelitian di bidang farmakologi, toksikologi, identifikasi dan isolasi zat aktif yang terdapat dalam tumbuhan (Leny, 2006). Salah satu famili tumbuhan di hutan tropis yang berpotensi sebagai sumber bahan kimia bioaktif dan jumlahnya relatif besar adalah Moraceae. Famili Moraceae adalah Artocarpus yang terdiri dari 50 spesies dan tersebar mulai dari Asia Selatan, Asia tenggara hingga kepulauan Solomon, kepulauan Pasifik, Australia Utara dan Amerika Tengah. Di pulau Kalimantan terdapat 25 spesies, dimana 13 spesies di antaranya endemik, namun baru dua spesies yang dimanfaatkan yaitu : Artocarpus heterophyllus dan A. integer.

Berdasarkan studi literatur, diketahui bahwa sejumlah spesies Artocarpus banyak menghasilkan senyawa golongan terpenoid, dan flavonoid. Keunikan struktur metabolit sekunder pada Artocarpus menghasilkan efek yang sangat luas, antara lain sebagai anti bakteri, anti platelet, anti fungal, antimalaria sitotoksik dan anti diabetes.

Penelitian terdahulu, terhadap famili yang sama yakni bahwa pada kulit akar dan kayu Artocarpus champeden (cempedak) dalam ekstrak metanol fraksi etil asetat telah ditemukan dua senyawa baru flavonoid yakni masing-masing senyawa Artoindonesianin A dan Artoindonesianin B. Penemuan ini mengindikasikan bahwa pada genus yang sama berpotensi sebagai sumber flavonoid atau senyawa metabolit sekunder lainnya.

Berdasarkan uraian diatas bahwa tumbuhan dengan famili yang sama cenderung mempunyai kemiripan senyawa yang dikandungnya atau secara umum mengandung konstituen karakteristik lain yang secara struktur terkait. Penyebaran flavonoid dalam tumbuhan ini ialah adanya kecenderungan yang kuat bahwa tumbuhan yang secara taksonomi berkaitan akan menghasilkan flavonoid yang 
jenisnya serupa. Salah satu spesies Artocarpus yang belum ditelitii kandungan kimianya secara lengkap adalah kulit batang Terap (Artocarpus odoratissimus).

Berdasarkan latar belakang di atas maka penelitian ini dilakukan karena kulit batang terap (Artocarpus odoratissimus) merupakan salah satu jenis famili Artocarpus yang kemungkinan mengandung beberapa senyawa metabolit sekunder dan memiliki efek toksisitas yang dapat memberikan banyak manfaat bagi kesehatan masyarakat.

Antioksidan adalah penghambat adanya radikal bebas yang dapat merusak sel-sel makhluk hidup akibat kondisi oksidasi dan ketidakseimbangan radikal bebas yang menyebabkan gangguan terhadap metabolisme dalam sel. Radikal bebas adalah spesies yang tidak stabil karena memiliki elektron yang tidak berpasangan dan mencari pasangan elektron dalam makromolekul biologi. Protein, lipida, dan DNA dari sel manusia yang sehat merupakan sumber pasangan elektron yang baik. Kondisi oksidasi dapat menyebabkan kerusakan protein dan DNA, kanker, penuaan, dan penyakit lainnya (Ozyurt et al., 2008).

Berbagai metode digunakan untuk mengukur aktivitas antioksidan produk makanan, dapat memberikan hasil yang bervariasi tergantung pada keberadaan radikal bebas tertentu yang digunakan sebagai reaktan. Metode yang digunakan pada penentuan aktivitas antioksidan ekstrak kulit batang terap (Artocarpus odoratissimus blanco) 'pada penelitian ini adalah metode DPPH. Metode ini dipilih karena memiliki beberapa kelebihan seperti teknis simpel, dapat dikerjakan dengan cepat dan hanya membutuhkan spektrofotometer UV-Vis. Prinsip metode uji antioksidan DPPH didasarkan pada reaksi penangkapan hidrogen oleh DPPH dari senyawa antioksidan. DPPH berperan sebagai radikal bebas yang diredam oleh antioksidan dari sampel. Selanjutnya DPPH akan diubah menjadi DPPH-H (bentuk tereduksi DPPH) oleh senyawa antioksidan (Karadag, 2009).

Sebagai langkah awal pengembangan tumbuhan Terap sebagai obat, dibutuhkan uji pendahuluan yang memberikan informasi mengenai aktivitas yang ditimbulkan oleh ekstrak tumbuhan. Untuk itu perlu dilakukan uji atau studi yang berkaitan dengan toksisitas dari tumbuhan terap. Metode prediksi toksisitas Brine 
Shrimp Lethality Test (BSLT) umum dilakukan sebagai uji pendahuluan dalam penelitian penapisan aktivitas pada ekstrak bahan alam.

Brine Shrimp Lethality Test (BSLT) merupakan salah satu metode skrining untuk mengetahui ketoksikan suatu ekstrak ataupun senyawa bahan alam. Uji toksisitas ini dapat diketahui dari jumlah kematian larva A. salina Leach. karena pengaruh ekstrak atau senyawa bahan alam pada konsentrasi yang diberikan. Metode ini dilakukan dengan menentukan besarnya nilai LC50 selama 24 jam. Data tersebut dianalisis menggunakan probit analisis untuk mengetahui nilai LC50 . Jika nilai LC50 masing-masing ekstrak atau senyawa yang diuji kurang dari 1000 $\mu \mathrm{g} / \mathrm{mL}$ maka dianggap menunjukkan adanya aktivitas biologik, sehingga pengujian ini dapat digunakan sebagai skrining awal terhadap senyawa bioaktif yang diduga berkhasiat sebagai antikanker (Ramdhini, 2010).

\section{METODE PENELITIAN}

\section{Bahan}

Simplisia kulit batang terap(Artocarpus odoratissimus Blanco.), etanol, nheksana, etil asetat, n-butanol, metanol pro analisis, air suling, pereaksi Dragendroff, pereaksi Mayer, asam klorida pekat, serbuk magnesium, besi (III) klorida, asam asetat glasial asam sulfat pekat, kalium hidroksida, larva udang Artemia salina Leach, air laut dan pereaksi DPPH (1,1-diphenyl-2-picrylhydrazyl).

\section{Peralatan}

Seperangkat alat maserasi, rotary evaporator (Büchi rotavapor $R$-200), timbangan analitik (Precisa XB 220A), tabung reaksi (Pyrex), tangas air (waterbath), labu ukur gelap (Pyrex), pipet tetes (Pyrex), corong (Pyrex), mikropipet, batang pengaduk, kertas Whatmann, aluminium foil, gelas kimia (Pyrex), labu ukur (Pyrex), vial, cawan penguap, kertas saring, corong pisah (Pyrex), wadah penetas, dan lampu 60 watt, tabung reaksi bertutup (Pyrex), mikro pipet, vortex mixer $(H-V M-400)$, kuvet $\left(\right.$ Brand $\left.^{\circledR}\right)$, spektrofotometer UV-Vis (Spectrophotometer Double Beam Halo DB-209 Dynamica). 


\section{Prosedur Penelitian}

\section{Ekstraksi}

Metode ekstraksi yang digunakan dalam penelitian ini adalah maserasi, yaitu simplisia kulit batang Terap (A.odoratissimus Blanco) dimaserasi dengan menggunakan pelarut metanol dan disimpan di tempat terlindung daricahaya matahari sambil sesekali dikocok. Maserasi dilakukan berkali-kali hingga diperoleh filtrat jernih. Hasilmaserasi disaring dan dipekatkan dengan Rotary evaporator. Ekstrak yang diperoleh disebut sebagai ekstrak kasar methanol.

\section{Perhitungan Rendemen}

Ditimbang kulit batang terap segar, kulit batang terap yang telah dikeringkan (simplisia) dan ekstrak metanol hasil maserasi. Selanjutnya dicatat dan dihitung jumlah rendemen sesuai dengan rumus perhitungan rendemen ekstrak yaitu berat ekstrak (g) dibagi dengan berat sampel kering sebelum ekstraksi (g) dikali 100\%, sehingga diperoleh nilai persen (\%) rendemen.

\section{Uji fitokimia}

Uji fitokimia dilakukan untuk mengetahui jenis metabolit sekunder yang terkandung pada ekstrak kasar metanol Terap (A. odoratissimus Blanco) serta fraksi kloroform dan hasil dari uji kromatografi kolom Vakum cair dan kromatografi kolom flash. Masing-masing dilarutkan sesuai dengan pelarutnya.

\section{Alkaloid}

Sebanyak $2 \mathrm{~mL}$ ekstrak diuapkan di atas cawan porselin. Residu yang dihasilkan kemudian dilarutkan dengan $5 \mathrm{~mL} \mathrm{HCl} 2 \mathrm{M}$. Larutan yang diperoleh dibagi ke dalam 3 tabung reaksi. Tabung pertama berfungsi sebagai blanko, ditambahkan dengan 3 tetes $\mathrm{HCl} 2 \mathrm{M}$. Tabung kedua ditambahkan 3 tetes pereaksi Dragendorff dan tabung ketiga ditambahkan 3 tetes pereaksi Mayer. Pada pereaksi Dragendorff akan terbentuk endapan berwarna jingga sedangkan pereaksi Mayer akan terbentuk endapan kuning yang menandakan positif adanya alkaloid.

\section{Fenolik}

Ekstrak sampel sebanyak $1 \mathrm{ml}$ dimasukkan ke dalam tabung reaksi untuk dilakukan pengujian fenolik dengan cara ekstrak ditambahkan pereaksi $\mathrm{FeCl} 3$ 1\%, jika terjadi warna hitam menunjukkan adanya senyawa fenolik. 


\section{Flavanoid}

Sebanyak $2 \mathrm{~mL}$ ekstrak ditambahkan dengan air panas secukupnya, kemudian dididihkan selama 5 menit lalu disaring. Filtrat sebanyak $5 \mathrm{~mL}$ ditambahkan 0,05 mg serbuk $\mathrm{Mg}$ dan $1 \mathrm{~mL} \mathrm{HCl}$ pekat, kemudian dikocok kuat-kuat. Uji positif ditunjukkan dengan terbentuknya warna merah, kuning atau jingga.

\section{Tanin}

Sebanyak $1 \mathrm{~mL}$ ekstrak ditambahkan dengan beberapa tetes larutan besi (III) klorida $10 \%$. Jika terjadi warna biru tua atau hitam kehijauan menunjukkan adanya tanin.

\section{Steroid}

Sebanyak $2 \mathrm{~mL}$ ekstrak ditambahkan $\mathrm{CH}_{3} \mathrm{COOH}$ anhidrat sebanyak 10 tetes dan $\mathrm{H}_{2} \mathrm{SO}_{4}$ pekat sebanyak 2 tetes. Larutan dikocok perlahan dan dibiarkan selamabeberapa menit. Adanya steroid ditunjukan oleh warna biru atau hijau, sedangkan triterpenoid memberikan warna merah atau ungu.

\section{Saponin}

Sebanyak 2-3 mL ekstrak dimasukkan ke dalam tabung reaksi, kemudian ditambahkan $10 \mathrm{~mL}$ air panas lalu dikocok kuat-kuat selama 10 detik, kemudian didinginkan lalu ditambahkan 1 tetes $\mathrm{HCl} 2 \mathrm{~N}$. Uji positif ditunjukkan dengan terbentuknya buih yang stabil setinggi 1-10 cm selama tidak kurang dari 10 menit.

\section{Uji BSLT}

Pengujian BSLT dilakukan dengan menggunakan larva Artemia salina Leach yang telah ditetaskan dalam media air laut selama 48 jam. Pengujian dilakukan pada ekstrak metanol, kulit batang terap. Ekstrak yang sukar larut dalam air laut ditambahkan tween sebagai peningkat kelarutan. Pengujian dilakuakan pada konsentrasi 31.25, 62.5, 125, 250, 500 dan 1000 ppm. Disiapkan wadah untuk pengujian, untuk masing-masing seri konsentrasi, selanjutnya pada tiap konsentrasi larutan dimasukkan 10 ekor larva Arthemia salina. Pengamatan dilakukan selama 24 jam terhadap kematian larva Arthemia salina dimana setiap konsentrasi dilakukan tiga kali pengulangan. Ditentukan nilai LC50 dari jumlah kematian larva udang Arthemia salina. 


\section{Uji Aktivitas Antioksidan}

Dibuat larutan DPPH 40 ppm dalam pelarut metanol. Dilakukan pengujian dengan menggunakan ekstrak metanol, kulit batang terap dengan lima variasi konsentrasi yaitu konsentrasi 20, 40, 60, 80 dan 100 ppm. larutan ekstrak-DPPH kemudian diinkubasi selama 30 menit. Dilakukan pengukuran absorbansi dengan menggunakan spektrofotometer UV-Vis pada panjang gelombang $515.5 \mathrm{~nm}$. Dilakukan replikasi sebanyak 3 kali untuk setiap variasi konsentrasi. Ditentukan nilai $\mathrm{IC}_{50}$ dari ekstrak dengan terlebih dahulu menentukan presentase peredaman $\mathrm{DPPH}$.

\section{HASIL DAN PEMBAHASAN}

Simplisia kulit batang terap sebanyak $\pm 1 \mathrm{~kg}$ dimaserasi dengan pelarut metanol selama $2 \times 24$ jam pada suhu kamar $\left(25^{\circ} \mathrm{C}\right)$. Metode maserasi dipilih sebagai cara ekstraksi dikarenakan proses yang mudah dan sederhana. Setelah disaring, residu yang diperoleh dapat diekstraksi kembali dengan menggunakan pelarut yang sama. Metanol digunakan sebagai pelarut awal karena metanol merupakan salah satu pelarut yang dapat melisiskan membran sel pada tanaman dan memiliki struktur molekul yang kecil sehingga mampu menembus jaringan tumbuhan untuk menarik senyawa aktif keluar. Pada proses maserasi, metanol akan masuk ke rongga sel menembus dinding sel kulit batang terap melarutkan zat aktif yang ada dalam sel sehingga konsentrasi yang tinggi terbentuk di bagian dalam kulit batang terap. Karena perbedaan konsentrasi zat aktif di dalam dan di luar sel menyebabkan terjadinya difusi zat aktif yang ada dalam sel akan keluar sel. Demikian seterusnya sampai terjadi kesetimbangan konsentrasi antara larutan disebelah dalam dan disebelah luar sel.

Tabel 1. Kandungan metabolit sekunder ekstrak kulit batang terap.

\begin{tabular}{ccc}
\hline No & Uji & Hasil \\
\hline 1 & Alkaloid & + \\
2 & Fenolik & + \\
3 & Flavanoid & + \\
4 & Tanin & + \\
5 & Steroid & - \\
6 & Saponin & + \\
\hline
\end{tabular}


Hasil maserat yang diperoleh dipekatkan dengan Rotary evaporator dengan hasil warna ekstrak coklat dan kental. Rotary evaporator mempermudah proses penguapan pelarut dengan memperkecil tekanan dengan vakum sehingga saat temperatur berada di bawah titik didih pelarut maka pelarut dapat menguap. Rotary evaporator lebih sering digunakan karena mampu menguapkan pelarut dibawah titik didih sehingga zat yang terkandung di dalam pelarut tidak rusak oleh suhu tinggi. Sehingga diperoleh ekstrak sebanyak 32.6 gr. Dengan jumlah rendemen ekstrak sebanyak $3.26 \%$.

Skrining fitokimia atau uji metabolit sekunder adalah metode analisis kandungan metabolit sekunder pada suatu bahan secara kualitatif. Analisis metabolit sekunder pada penelitian ini dilakukan terhadap kulit batang terap yang telah dimaserasi menggunakan pelarut. Pengujiannya dilakukan dengan cara menguji sedikit sampel dari ekstrak, lalu ditambahkan reagen sesuai dengan senyawa yang akan diidentifikasi. Senyawa-senyawa yang diperiksa keberadaannya adalah alkaloid, fenolik, flavonoid, tanin, saponin dan steroid atau triterpenoid. Hasil skrining metabolit sekunder seperti ditunjukan pada tabel 1 diperoleh bahwa pada ekstrak metanol kulit batang terap positif mengandung metabolit sekunder golongan alkaloid, fenolik, tanin, flavanoid dan saponin.

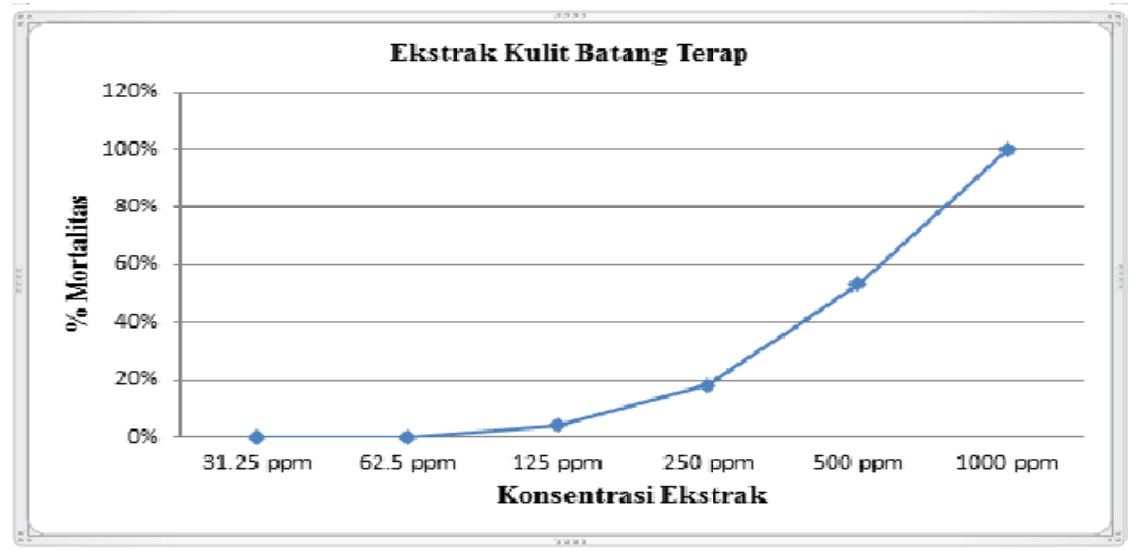

Gambar 1. Toksisitas ekstrak kulit batang terap terhadap larva udang A.salina.

Uji toksisitas terhadap larva udang Arthemia salina Leach atau Brine Lethality Shrimp Test (BSLT) dapat digunakan sebagai uji pendahuluan pada 
penelitian yang mengarah pada uji sitotoksik. Korelasi antara uji toksisitas akut ini dengan uji sitotoksik adalah jika mortalitas terhadap Arthemia salina Leach yang ditimbulkan memiliki harga LC50< $1000 \mu \mathrm{g} / \mathrm{mL}$. Parameter yang ditunjukkan untuk menunjukkan adanya aktivitas biologi pada suatu senyawa pada Arthemia salina Leach adalah kematiannya. Adapun range dari toksisitas BSLT yaitu :
LC50 $\leq 30 \mathrm{ppm}$
: Sangat toksik
$31 \mathrm{ppm} \leq \mathrm{LC} 50 \leq 1000$
: Toksik
LC50 > 1000 ppm
: tidak toksik

Pada pengujian ini dilakukan penambahan tween sebagai peningkat kelarutan karena ekstrak yang sedikit sukar larut dalam air laut. Pengujian toksisitas ekstrak kulit batang terap dengan metode BSLT dimana pada pengujiannya menggunakan enam variasi konsentrasi yaitu 31.25, 62.5, 125, 250, 500 dan 1000 ppm. dengan pengulangan sebanyak 3 kali pada setiap variasi konsentrasi. Kontrol dibuat dengan memberikan perlakuan yang sama terhadap larva udang namun tanpa penambahan ekstrak uji. Pada kontrol juga ditambahkan tween dengan maksud menyamakan kondisi dan perlakuan seperti pada kelompok uji sehingga hasil yang diperoleh dapat dianalisa bahwa kematian larva udang yang terjadi pada kelompok uji bukan disebabkan oleh adanya penambahan peningkat kelarutan melainkan karena efek dari penambahan ekstrak kulit batang terap.

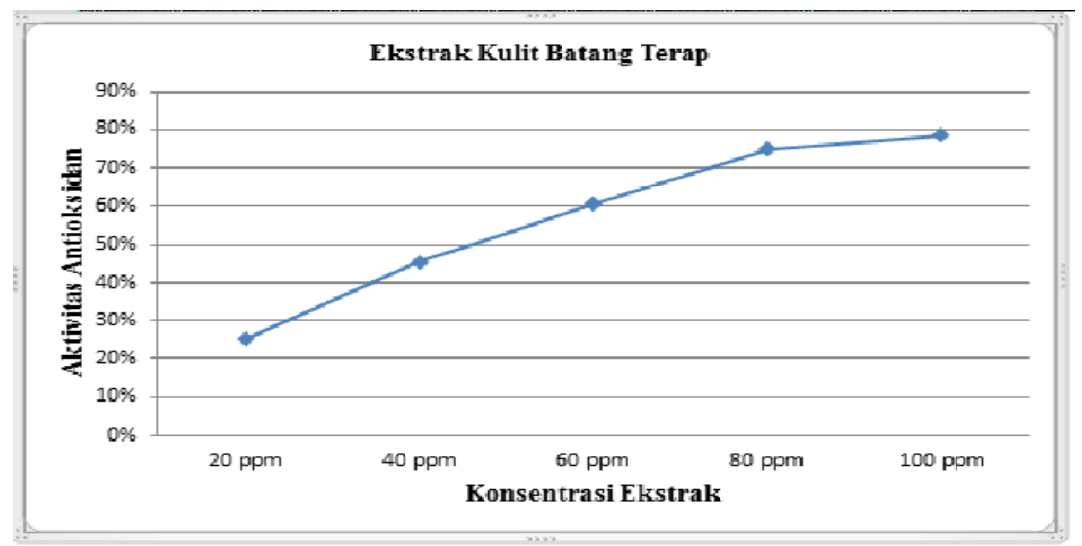

Gambar 2. Aktivitas antioksidan ektrak kulit batang terap terhadap peredaman radikal DPPH. 
Hasil dari pengujian toksisitas akut kulit batang terap terhadap larva Arthemia salina pada ekstrak metanol ditunjukkan pada gambar 2 dimana grafik kematian larva udang menunjukkan nilai $\mathrm{LC}_{50}$ ekstrak tersebut adalah $462.38 \mathrm{ppm}$. Nilai LC $_{50}$ pada hasil uji menunjukkan konsentrasi dimana ekstrak tersebut dapat membunuh sebanyak 50\% hewan atau larva uji. Sehingga dapat dinyatakan bahwa kulit batang terap mempunyai aktivitas biologik dimana nilai $\mathrm{LC}_{50}$ berada lebih rendah dari 1000 ppm.

Uji aktivitas antioksidan dari ekstrak kulit batang terap dilakukan melalui reaksi peredaman radikal 2,2-diphenyl-1-picrylhydrazyl (DPPH). Radikal bebas dikenal sebagai faktor utama dalam kerusakan biologi, dan DPPH digunakan untuk mengevaluasi aktivitas peredaman radikal bebas dari suatu antioksidan alami. DPPH yang merupakan suatu molekul radikal bebas dengan warna ungu dapat berubah menjadi senyawa yang stabil dengan warna kuning oleh reaksi dengan antioksidan, dimana antioksidan memberikan satu elektronnya pada DPPH sehingga terjadi peredaman pada radikal bebas DPPH. Uji DPPH merupakan metode yang mudah untuk menapis sejumlah kecil molekul antioksidan karena reaksi dapat diamati secara visual menggunakan KLT, atau juga intensitasnya dapat dianalisis melalui spektrofotometri sederhana. Elektron tak berpasangan pada DPPH memberikan suatu absorbsi yang kuat, pada panjang gelomabang maksimum $\lambda=515.5 \mathrm{~nm}$ dan berwarna ungu. Peredaman radikal bebas oleh antioksidan terjadi ketika elektron tak berpasangan menjadi berpasangan dengan adanya sebuah donor hidrogen, sehingga membentuk DPPH yang lebih stabil.

Peredaman radikal oleh senyawa antioksidan umumnya disebut dengan inhibisi, sedangkan besarnya peredaman dinyatakan dalam persen inhibisi. Penentuan konsentrasi aktivitas antioksidan dilakukan dengan menentukan nilai $\mathrm{IC}_{50}$ (Inhibitory Concentration) atau besarnya konsentrasi senyawa yang diduga beraktivitas sebagai antioksidan terhadap peredaman radikal DPPH. Pengujian aktivitas antioksidan kulit batang terap dilakukan dengan lima variasi konsentrasi dengan masing-masing 3 replikasi setiap konsentrasinya. Blanko digunakan dengan menggunakan larutan DPPH dan penambahan pelarut metanol sesuai dengan penggunaan pelarut pada larutan ekstrak. 
Senyawa bahan alam yang diyakini mempunyai aktivitas sebagai antioksidan adalah senyawa fenolik ataupun polifenol pada flavonoid. Pada senyawa polifenol, aktivitas antioksidan berkaitan erat dengan struktur rantai samping dan juga substitusi pada cincin aromatiknya. Kemampuannya untuk bereaksi dengan radikal bebas DPPH dapat mempengaruhi urutan kekuatan antioksidannya. Aktivitas peredaman radikal bebas senyawa polifenol diyakini dipengaruhi oleh jumlah dan posisi hidrogen fenolik dalam molekulnya. Dengan demikian aktivitas antioksidan yang lebih tinggi akan dihasilkan pada senyawa fenolik yang mempunyai jumlah gugus hidroksil yang lebih banyak pada inti flavonoidnya.

Senyawa fenolik ini mempunyai kemampuan untuk menyumbangkan hidrogen, maka aktivitas antioksidan senyawa fenolik dapat dihasilkan pada reaksi netralisasi radikal bebas yang mengawali proses oksidasi atau pada penghentian reaksi radikal berantai yang terjadi. Senyawa alkaloid, terutama indol, memiliki kemampuan untuk menghentikan reaksi rantai radikal bebas secara efisien. Senyawa radikal turunan dari senyawa amina ini memiliki tahap terminasi yang sangat lama

Hasil pengujian aktivitas antioksidan kulit batang terap terhadap peredaman radikal DPPH diperoleh nilai $\mathrm{IC}_{50}$ dari ekstrak metanol kulit batag terap adalah 50 ppm (gambar 2). Dari data tersebut dapat disimpulkan bahwa aktivitas antioksidan kulit batang terap pada ekstrak metanol adalah sangat kuat. Hasil ini dapat dikaitkan dengan kandungan metabolit sekunder yang terkandung dalam kulit batang terap yang mana telah diuji sebelumnya. Pada ekstrak metanol mempunyai aktivitas antioksidan yang kemungkinan disebabkan kandungan senyawa alkaloid, flavanoid dan fenolik sebagai senyawa peredam radikal.

\section{KESIMPULAN}

Dari hasil penelitian dapat disimpulkan bahwa ekstrak metanol kulit batang terap memiliki potensi sebagai antioksidan yang kuat, hal ini ditandai dengan nilai $\mathrm{IC}_{50}$ yang diperoleh sebesar $50 \mathrm{ppm}$, dan diperkuat dengan adanya metabolit sekunder yang berkhasiat sebagai antioksidan yaitu alkaloid, flavonoid, dan fenolik. 
Sedangkan pada pengujian toksisitas dengan metode BSLT ekstrak kulit batang terap berada pada range pestisida, dimana nilai $\mathrm{LC}_{50}$ sebesar 462,38 ppm.

\section{DAFTAR PUSTAKA}

Karadag, A., Ozcelik, B. and Saner, S., 2009, Review of Methods to Determine Antioxidant Capacities. Food Anal. Methods. 2. 41-60.

Leny, S. 2006. "Isolasi dan Uji Bioaktifitas Kandungan Kimia Utama Puding Merah Dengan Metode Uji Brine Shirmp".Karya Ilmiah Jurusan Kimia FMIPA, Universitas Sumatra Utara.

Ozyurt M, Tekgunduz A, Karagoz B, Bilgis O, Bilekli F., 2008, Febril neutropenia etiology in a hematology department. Europe Journal General Medicine Vol. 5(4); 228-231.

Ramdhini, R. N., 2010, Uji Toksisitas Terhadap Artemia Salina Leach. dan Toksisitas Akut Komponen Bioaktif Pandanus Conoideus Var. Conoideus Lam. sebagai Kandidat Antikanker. Thesis. Universitas Sebelas Maret Surakarta. 